\title{
What Best Predicts Corporate Bank Loan Defaults? An Analysis of Three Different Variable Domains
}

\author{
Keijo Kohv and Oliver Lukason*
}

School of Economics and Business Administration, University of Tartu, 51009 Tartu, Estonia; kohvkeijo@gmail.com

* Correspondence: oliver.lukason@ut.ee

\begin{abstract}
This paper aims to compare the accuracy of financial ratios, tax arrears and annual report submission delays for the prediction of bank loan defaults. To achieve this, 12 variables from these three domains are used, while the study applies a longitudinal whole-population dataset from an Estonian commercial bank with 12,901 observations of defaulted and non-defaulted firms. The analysis is performed using statistical (logistic regression) and machine learning (neural networks) methods. Out of the three domains used, tax arrears show high prediction capabilities for bank loan defaults, while financial ratios and reporting delays are individually not useful for that purpose The best default prediction accuracies were $83.5 \%$ with tax arrears only and $89.1 \%$ with all variables combined. The study contributes to the extant literature by enhancing the bank loan default prediction accuracy with the introduction of novel variables based on tax arrears, and also by indicating the pecking order of satisfying creditors' claims in the firm failure process.
\end{abstract}

Keywords: failure prediction; corporate loan defaults; tax arrears; reporting delays; financial ratios

check for updates

Citation: Kohv, Keijo, and Oliver Lukason. 2021. What Best Predicts Corporate Bank Loan Defaults? An Analysis of Three Different Variable Domains. Risks 9: 29. https:// doi.org/10.3390/risks9020029

Received: 22 November 2020

Accepted: 22 January 2021

Published: 25 January 2021

Publisher's Note: MDPI stays neutral with regard to jurisdictional claims in published maps and institutional affiliations.

Copyright: (c) 2021 by the authors. Licensee MDPI, Basel, Switzerland. This article is an open access article distributed under the terms and conditions of the Creative Commons Attribution (CC BY) license (https:// creativecommons.org/licenses/by/ $4.0 /)$.

\section{Introduction}

Business failure prediction is a constantly evolving stream of literature. The research field is important because when companies fail, they can have a significantly negative social and financial impact on owners, employees, creditors, clients and other stakeholders of the failed businesses, but also to economies and societies in general (Alaka et al. 2018; CamachoMiñano et al. 2015; Wu 2010). Business failure as a phenomenon has a broad range of definitions. For example, in their study Dias and Teixeira $(2017$, p. 3) analysed 201 journal articles on the topic and found that business failure is most commonly defined as an event of "bankruptcy, business closure, ownership change, and failure to meet expectations." In addition, business failure could mean bond default, bank loan default, delisting of a company, government intervention and liquidation (Altman and Narayanan 1997). The most commonly used definition in failure-prediction studies is bankruptcy; however, it is only one of the many negative events in the business failure process (Balcaen and Ooghe 2006). Weitzel and Jonsson (1989) created a stage model for the business failure process, where every stage is seen as some sort of failure. According to the stage model (Weitzel and Jonsson 1989, p. 102), payment default is connected with the crisis stage, logically seen as a result of factors such as blindness, inaction and faulty actions from the earlier stages. At that stage, effective reorganization might save the company, and thus, the prediction of it is potentially more beneficial for the stakeholders than forecasting bankruptcy. Payment default is among the most serious warning signals that a company is in risk of terminal failure (Balcaen and Ooghe 2006).

From a creditor's point of view, in order to avoid negative consequences it is vital to assess a firm's probability of failure to achieve sounder credit decisions and to appropriately compensate the risk in expected returns, or to avoid crediting unhealthy firms in the first place (Alaka et al. 2018; Atiya 2001; Xu and Zhang 2009). Many banks and other credit providers have set up an automated system giving early warning signals about potential 
failure, which provides a necessary window for the stakeholders to take action and try to minimize negative consequences (Laitinen 2008). Still, the prediction of loan default might be more difficult when compared with terminal failure (e.g., bankruptcy), because negative signals might not be observable through publicly available information.

Classical studies of the research area include univariate (Beaver 1966) and multivariate (Altman 1968) failure-prediction models that apply historical accounting data (financial ratios) as predictor variables. While pioneering studies were based on classical statistical techniques, the latest innovations in failure prediction take advantage of artificial intelligence and machine learning tools. It can be concluded that there are numerous techniques applied in hundreds of studies that mostly use financial ratios to create failure-prediction models with high prediction accuracies (for example, see the review by Sun et al. 2014). Still, there are comparatively very few studies about corporate bank loan default prediction, partly probably because of difficulties with obtaining relevant information publicly. Thus, detailed knowledge is missing from the extant literature, whether variables beneficial for predicting failure definitions positioned further in the timeline (e.g., bankruptcy, involuntary liquidation) are applicable in case of forecasting loan defaults positioned much earlier in the timeline.

Derived from the latter, the paper aims to compare the accuracy of financial ratios, tax arrears and annual report delays in bank loan default prediction. A three-layer analysis (i.e., single variables, all variables from a domain, and finally, a cross-domain approach) is performed by using two methods: logistic regression and neural networks. Such an approach avoids the single-method bias and gives a holistic perspective about the prediction accuracies through the three layers. As noted, in the failure process default is located before permanent insolvency, and thus, default prediction capabilities of financial ratios, which are commonly used in the context of permanent insolvency, could be questionable. The latter is subject to several theoretical considerations elaborated in the literature review (see Section 2.1 for more details). Therefore, two novel domains, namely tax arrears and reporting delays, are included in the current study. Neither of those two has been applied in prior literature in the current setting, i.e., for loan default prediction, although there are a few examples available of their successful implementation in the corporate bankruptcy prediction setting (see Section 2.2 for more details). Thus, the main contribution of the paper to the extant literature is the provision of a novel approach for the prediction of bank loan defaults.

The paper is structured as follows. Literature review consists of two subsections: first, the theoretical background of company failure, and second, an overview of financial and non-financial variables used in the previous research. This is followed by an overview and explanation of data, variables and methods used in the empirical part. Thereupon, the results and their discussion are presented. The paper ends with a conclusion in the last section.

\section{Review of Literature}

\subsection{Loan Payment Default in the Context of Firm Failure}

The term payment default has several definitions. In general it can be said that a payment default occurs when a firm is unable to pay its financial obligations as they are due (Altman 1968; Beaver 1966). In other words, a debtor is experiencing financial distress, which finally may lead to business failure (Höglund 2017, p. 369). Altman et al. (2010) also emphasize the importance to differentiate between firm failure and firm closure, while Headd (2003) showed that about a third of all closed businesses were financially successful, thus not all closures are failures. Firms that are experiencing financial distress may never face legal failure (i.e., bankruptcy). Besides bankruptcy, additional outcomes for a financially distressed (i.e., defaulted) company include "dissolution, merger, liquidation or sustaining operations" (Camacho-Miñano et al. 2015, p. 341). A recovery from payment default is achieved usually through restructuring (reorganization), either in an informal or court-supervised form. In case a firm is financially distressed and temporarily unable to 
pay its obligations, it could avoid bankruptcy by using a reorganization option available in many countries worldwide, subject to a country-specific legal framework (Laitinen 2008). Even though existing practice shows a relatively small success rate of reorganizations (Lukason and Urbanik 2013), similarly to failure prediction, the outcome of reorganization can be predicted. In their Estonia-based study, Lukason and Urbanik (2013) showed that financial variables reflecting solvency, profitability and capital structure domains were not remarkably different between successfully and unsuccessfully reorganized firms. Thus, their usage for the prediction of defaults might be questionable. In contrast, non-financial information, such as economic sector, firm size, shareholder structure, and availability of reorganization plan do greatly impact the prediction accuracy of the reorganization outcome (Camacho-Miñano et al. 2015; Laitinen 2008; Lukason and Urbanik 2013).

The theoretical consideration behind the potentially poor performance of financial ratios and good performance of other variables to predict loan defaults is several-fold. It has been vividly shown in the SME (see European Commission 2020 for the definition) segment that in the failure process, last annual reports reflecting the financial situation exactly one year before bankruptcy in many cases do not show signs of potential failure (Lukason et al. 2016; Lukason and Laitinen 2019). Therefore, it is essential to include information other than financial ratios in the prediction models. The first possibility is to use reporting delays, as it has been shown that firms in poor financial situation often engage in the unethical behaviour of delaying financial information (Altman et al. 2010; Lukason 2013; Lukason and Camacho-Miñano 2019). Still, the pre-default timeframe could be too short for a lengthy violation behaviour to occur. The second possibility is to use other types of defaults, because firms might be engaged in prioritizing creditors by means of creating a ranking of whose claims to satisfy first. Such a pecking-order approach to the prioritization of unpaid debt has not been elaborated in the failure prediction literature, although it could be a logical assumption because of the prioritization of claims in most of the available insolvency jurisdictions. The study by Lukason and Andresson (2019) points to the possibility that credit due to state, i.e., tax arrears, could occur before other claims. Therefore, tax arrears could serve as a signal of forthcoming bank loan default.

Because this study applies a dataset from a commercial bank and has the main focus on payment defaults of credit contracts, default in this paper is defined according to the Basel II framework that states: " ... the obligor is past due more than 90 days on any material credit obligation to the banking group." (Basel Committee on Banking Supervision 2016, p. 8). Thus, unlike bankruptcy, which as a form of business failure is subject to each country's legal and financial frameworks, loan-payment default is universally defined through Basel II (Bhimani et al. 2010), and therefore, enables the international comparability of the obtained results. Thus, when a company is 90 days overdue in payments, it indicates serious financial distress. Nevertheless, in failure-prediction studies, existing research about loan defaults is scarce compared to bankruptcy studies. That is probably because loan payment default usually occurs in the context of the confidential lender-borrower relationship, making the data itself also strictly confidential. Therefore, a majority of the studies that have previously used defaults as dependent variables have actually considered bankruptcy or permanent insolvency as a "default" (e.g., Altman and Sabato 2007; Ciampi 2018), because that information is easily accessible and specifically defined in certain country context.

\subsection{Financial and Non-Financial Variables for Firm Failure Prediction}

This paper relies on Iwanicz-Drozdowska et al. (2016) classification of variables into financial and non-financial, where the former are variables calculated by using information from annual financial statements, the latter being therefore all other variables. Even though Balcaen and Ooghe (2006, p. 79) concluded in their study that "there seem to be no superior predictor variables or superior methods" when it comes to firm failure prediction, it has been found in previous research that the most used and the most important financial variables are financial ratios that come from liquidity (current ratio, working 
capital/total assets), solvency (total debt/total assets) and profitability (net income/total assets) categories (Dimitras et al. 1996; Bellovary et al. 2007). Therefore, liquidity, solvency and profitability seem to best indicate financial distress in the firm failure process (Höglund 2017, p. 369).

Although the most used technique in failure prediction uses financial variables in the form of financial ratios calculated from a firm's financial statement, there are several limitations. Besides multicollinearity in between financial ratios that is frequently seen in relevant research, other weaknesses of financial variables are, firstly, the availability of data in a timely manner, and secondly, information asymmetry in the data. Researchers assume that the financial figures in financial statements give a true and a fair view of the company's financial situation. However, previous studies have shown that such an assumption does not hold always, especially with failing companies, where financial data might be manipulated in an attempt to hide or postpone the emergence of financial weaknesses (Balcaen and Ooghe 2006; Ciampi et al. 2020; Laitinen and Laitinen 2009). Additionally, in case a company is non-audited as smaller companies usually are, its reports are less reliable and often deliberately opaque, setting additional obstacles for relying only on financial variables in firm-failure prediction (Altman et al. 2010; Ciampi 2015, 2018). Moreover, because the majority of active companies worldwide consists of SMEs (including the dataset of present study), even small changes in absolute figures can lead to exaggerated changes in financial ratios (Ciampi 2015). At the same time SMEs have also relatively smaller financial buffers to withstand sudden financial distress (Beaver 1966). Relying on the finding of Lukason and Laitinen (2019) that even the latest annual report might not sufficiently indicate worsening of a firm's financial situation, and the fact that some of the commonly used financial ratios for large companies are completely ineffective for SMEs (Ciampi 2015), occurrences of payment defaults and decline of a firm in general can be sudden and quick (Ciampi et al. 2020).

Seeking to overcome the aforementioned limitations, recent studies have included non-financial independent variables in order to improve the accuracy of failure-prediction models (Ciampi 2015). As explained earlier, in failure-prediction literature, the term "non-financial variable" is commonly used by researchers for various variables other than financial ratios calculated by using financial statements. Prediction models that include non-financial variables such as previous payment patterns (Back 2005), corporate governance (Ciampi 2015), reporting and compliance (Altman et al. 2010), balanced scorecard information (Gabbi et al. 2020) and tax arrears (Lukason and Andresson 2019) have usually outperformed classical prediction models based solely on financial variables. Non-financial information, such as previous payment history, holds more updated information compared to financial data (Laitinen 2011). Thus, banks and other financial institutions, whose credit portfolio mainly consists of SMEs, must implement non-financial information in their credit scoring models, because the models that are based only on financial ratios would be ineffective (McCann and McIndoe-Calder 2015). In their international study, Altman et al. (2017, p. 166) showed that the inclusion of non-financial variables enhanced the classical Z-score model's accuracy, however, the results varied by countries. Of course, the usage of non-financial variables is always limited to country-specific data availability. Compared to financial variables, non-financial variables are typically less correlated with one another or with financial ratios (Altman et al. 2020). In addition, several studies (e.g., Altman and Sabato 2007; Ciampi 2015) have proven that the classical failure-prediction models that work well for large companies are not the best fit for SMEs.

While the literature on business failure prediction is vast and constantly growing, existing literature focusing specifically on bank loan payment default prediction is rare. The same can be said about the studies that have included non-financial variables for businessfailure prediction, thus leaving it a largely unexplored research area (Ciampi 2018). Articles where loan default (or a proxy of it) is used as the dependent variable or articles where the failure prediction model has incorporated non-financial variables have been summarized in Appendix A Table A1. 
The articles in Table A1 have analysed default prediction based on different nonfinancial information, such as firm age (Altman et al. 2010, 2017; Back 2005; Bhimani et al. 2013); firm size (Altman et al. 2010, 2017; Back 2005; Bhimani et al. 2013); industrial sector (Altman et al. 2010, 2017; Bhimani et al. 2013; Höglund 2017; Laitinen 2011); management characteristics (Back 2005; Bhimani et al. 2013; Ciampi 2015; Laitinen 2011); previous payment history (Back 2005; Ciampi et al. 2020; Laitinen 2011); corporate social responsibility (Ciampi 2018); tax arrears (Lukason and Andresson 2019); country of origin (Altman et al. 2017); financial support from partners (Bhimani et al. 2013); ownership of assets (Bhimani et al. 2013); stock price volatility (Atiya 2001); audit information (Altman et al. 2010); late filing of reports (Altman et al. 2010); and country court judgement (Altman et al. 2010).

It must be noted that while some of the variables have (high) failure-prediction capabilities, then others have mainly been used as context or control variables. Default prediction accuracies in the studies listed in Table A1 range from 73-93\%, whereby in all the studies, models that combined financial and non-financial information outperformed those that used financial information only. For example, in their study based on a very large U.K. dataset, Altman et al. (2010) gained a 13\% improvement in default-prediction model accuracy by including non-financial variables. The most used methods in the reviewed articles were logistic regression and artificial neural networks.

Among other findings in the existing literature related to non-financial information, a strong link can be found between financial distress and payment history: when the number of past payment delays increases, so does the probability of future financial difficulties (Back 2005; Laitinen 1999; Laitinen 2011). In their study based on Estonian firms, Lukason and Andresson (2019) showed that up to one year prior to bankruptcy, the prediction model using tax arrears has clearly better failure-prediction capabilities than the model using financial ratios, while the best results were obtained by combining financial information with tax arrears. Additionally, several studies have previously focused on non-compliance with regulations, indicating a clear link between late filing or non-submission of accounts with increased risk of financial distress and business failure (Altman et al. 2010; Lukason 2013; Lukason and Camacho-Miñano 2019).

\section{Dataset, Variables and Methods}

\subsection{Dataset}

The time period considered in this study spans 2013-2018, and thus, neglects the global financial crisis effects from the analysis. It is a period of stable economic growth with an average GDP chain growth of 3.2\% per year in Estonia (Statistics Estonia 2020). Three main sources are employed to gather necessary data for the analysis: (a) financial data and reporting delays dataset from the Estonian Business Register; (b) tax payment delays dataset from the Estonian Tax and Customs Board; (c) whole-population dataset from an Estonian commercial bank consisting of firms that had signed at least one credit contract during the period and are grouped as defaulted and non-defaulted. Breakdown of the dataset observations by studied years with quartile values of tax arrears and reporting delays can be followed in Table 1 below.

In this study, only these loan defaults are used, in case of which loan payment has been overdue for at least 90 days. Several earlier studies have used roughly equal-sized samples of defaulted and non-defaulted firms; however, this might create a bias because the non-defaulted sample would not represent the population it originates from (Lukason and Andresson 2019). Thus, this study is based on the whole population of firms in the context of an Estonian commercial bank. It includes firms from every economic sector, and there are no limitations in terms of company characteristics, albeit more than $90 \%$ of the companies are SMEs. The no-limit approach enrichens the dataset, and on the example of a specific commercial bank in essence provides a good representation of the Estonian corporate credit landscape in general. Moreover, Estonia as an advanced economy and one of the leading digital societies in the world is a long-time member of the European 
Union and a large share of its commercial banks are owned by Scandinavian banks; thus, the results of the study span over a single country context.

Table 1. Overview of the dataset.

\begin{tabular}{ccccccccccc}
\hline \multirow{2}{*}{ Year } & \multirow{2}{*}{$\begin{array}{c}\text { Number of } \\
\text { Observations }\end{array}$} & \multicolumn{3}{c}{ Maximum Tax Arrears in Euros } & \multicolumn{3}{c}{ Reporting Delay in Days } \\
\cline { 2 - 11 } & $\mathbf{D}$ & ND & Q1 & Q2 & Q3 & Q1-Q3 & Q1 & Q2 & Q3 & Q1-Q3 \\
\hline & 5 & 3808 & 504 & 1791 & 2378 & 0 & 0 & 0 & 0 & 0 \\
2013 & 15 & 884 & 229 & 1945 & 8492 & 0 & 0 & 0 & 0 & 0 \\
2014 & 40 & 1198 & 263 & 1263 & 8184 & 0 & 0 & 0 & 28 & 0 \\
2016 & 42 & 1752 & 1327 & 6121 & 18,837 & 0 & 0 & 0 & 71 & 0 \\
2017 & 20 & 2282 & 1728 & 6572 & 19,327 & 0 & 0 & 31 & 244 & 0 \\
2018 & 34 & 2821 & 213 & 1729 & 7061 & 0 & 0 & 0 & 120 & 0 \\
Total & 156 & 12,745 & & & & & & & &
\end{tabular}

Source: own elaboration. Note: D—defaulted; ND—non-defaulted; Q1 is the first quartile (25th percentile); Q2 is median value (50th percentile); Q3 is the third quartile (75th percentile). Information about the periods used to calculate respective variables can be followed in Section 3.3.

The dataset includes 12,901 observations, consisting of 156 defaults and 12,745 nondefaults. The low frequency of defaulted loans indicates a high quality of the credit portfolio. The observations are based on firms, not on credit contracts, meaning that a firm can only have up to one observation per year (albeit it could have signed more than one credit contract), therefore eliminating the potential bias by larger firms having several loan contracts. The defaulted observations are unique and each default observation occurs only once. In practice, in case a borrower has defaulted with any credit obligation, most commercial banks in Estonia have reserved themselves the right to prematurely terminate all the borrower's credit contracts. For instance, a situation where a firm has defaulted with some credit obligations, while continuing timely payments with remaining obligations, is very unlikely. Hence, the firm-based approach is more reasonable than the contract-based approach. The non-defaulted observations are not unique however, and as noted, they are limited to appear only once per year in their population, i.e., a non-defaulted company can have a minimum of one and a maximum of six observations in the dataset (one per each year during the observed period). Default is being used as an observed dependent variable, taking the form of either 1 for the defaulted or 0 for the non-defaulted firm in all prediction models.

\subsection{Financial Ratios}

From annual financial statements of firms, only financial ratios have been used in this paper, while Iwanicz-Drozdowska et al. (2016) also applied (transformed) financial figures (e.g., logarithm of total assets), changes in financial figures (e.g., sales growth rate) and changes in financial ratios. Financial ratios that are used in this study are in accordance with previous extensive literature reviews by Dimitras et al. (1996) and Bellovary et al. (2007), who showed that the most used domains in corporate-failure prediction are profitability, liquidity and solvency (solidity). It should be noted that SMEs in Estonia are allowed to report their annual financial statements with only the most essential figures, meaning that the reports are not as detailed as for large companies. Hence, it is reasonable to apply the most common financial ratios previously used in failure research in order to retain the maximum number of observations with the necessary data available to calculate the ratios. More specifically, the top eight ratios based on their individual accuracy have been selected among various financial ratios from the recent study by Lukason and Andresson (2019), who focused on a very similar context to current research, i.e., bankruptcy prediction of Estonian companies. Selected financial ratios and formulas are documented in Table 2. 
Table 2. Financial ratios' domains, abbreviations and formulas.

\begin{tabular}{|c|c|}
\hline Domain & Ratio Abbreviation and Formula \\
\hline Liquidity & CCLA $=\frac{(\text { cash-current liabilities })}{\text { total assets }}$ \\
\hline Liquidity & NWCA $=\frac{(\text { current assets-current liabilities })}{\text { total }}$ \\
\hline Profitability & NIA $=\frac{\begin{array}{c}\text { total al assets } \\
\text { tot income }\end{array}}{\text { thal scsots }}$ \\
\hline Profitability & $N I O R=\frac{\text { total assets }}{\text { net income }}$ \\
\hline Financial structure/solvency & $D A=\frac{\text { total debt }}{\text { total }}$ \\
\hline Activity/efficiency & ORA $=$ operating revenue \\
\hline Interest burden/solvency & $F R E O R=\frac{\text { (financial revenue }- \text { financial expenses })}{\text { total asets }}$ \\
\hline Interest hurden/solvency & 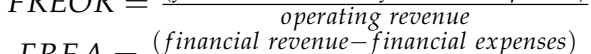 \\
\hline mimerest ouraen/sorvency & total assets \\
\hline
\end{tabular}

Source: formulas based on Lukason and Andresson (2019, p. 6).

In Estonia, companies are obliged to submit their annual reports to the Estonian Business Register within six months after the end of a 12-month fiscal period. In accordance with the explanation in Section 3.1, in this study, for the healthy (non-defaulted) companies, all available annual reports from years 2012 to 2017 are applied to calculate financial ratios. For the defaulted companies, a relevant annual financial statement prior to the default is used. For example, if a firm whose fiscal year ends in December defaulted in July 2014, then its 2013 annual report submission was due in June 2014, and thus, the 2013 report was used to calculate the ratios. Respectively, if the default occurred in March 2016, then the 2015 report's due date had not arrived, and therefore, the 2014 report was used for calculations. However, the companies that have higher failure risk tend to delay submitting annual reports or not submit them at all (Lukason and Camacho-Miñano 2019), resulting in the required up-to-date financial data often being unavailable for failed companies. To overcome this potential obstacle and retain as much data as possible, in case a relevant report is unavailable the study reverts to the latest available financial statement before the event of default to calculate the financial ratios. A similar approach has been used in the previous research (e.g., Back 2005). Firms that had no reports available at all were excluded from the dataset.

\subsection{Variables about Tax Arrears and Annual Report Delays}

Non-financial variables in this paper come from two main domains: (a) tax arrears, and (b) reporting delays. The collection of taxes in Estonia is administered by the Estonian Tax and Customs Board, while information about unpaid tax debt is publicly available. Companies in Estonia must pay taxes twice in the month following the month when taxes occurred (specifically on the 10th and 20th dates in the following month). In this study, all tax arrears are considered equal, so there is no classification between value added tax or employee-related taxes. In addition, no distinction was made between timed and untimed tax arrears, i.e., even if tax arrears are timed they reflect that a firm was not able to pay them in time. Tax arrears' information is applied as a time series of 12 month ends, while in the case of defaulted firms the 12-month period counts backwards as starting from the pre-default month, and for non-defaulted firms the 12-month periods are matching the calendar year. To capture different aspects of the tax arrears, three variables from Lukason and Andresson (2019) are applied: maximum (TMAX) and median (TMED) amount of tax arrears that are present in the month ends (i.e., on the last day of each month) and also the number of months, where on the last day of each month tax arrears were present (TCOUNT). Based on the motivation in Lukason and Andresson (2019), only tax arrears that are present in the month ends and are at least 100 euros are considered.

The reporting delays variable (RDD) was calculated as the number of days the annual report was overdue. Similarly as with the financial ratios' calculations, for the healthy (non-defaulted) firms all available annual reports from 2012 to 2017 are applied. RDDs are calculated using last-year reports by deducting the report due date (legal date that is six months after the end of the fiscal year) from the report submission date (actual 
date). Reports that were submitted before the due date had negative values, which were replaced with zero values (i.e., a no-delay situation). For the defaulted firms, the calculation principle is the same as with the non-defaulted firms, but only the reports prior to default events are used. If the default happened within the first six months of the running year $t$, then the report of the fiscal year $t-2$ is used. If the default happened after six months of the running year $t$, then the report of the fiscal year $t-1$ is used. In case the necessary report is missing (not submitted), then the latest available report is used.

The natural logarithms of maximum and median values of tax arrears were used in order to reduce skewness. In case an observation's TMAX or TMED is zero, then zero value is used instead of natural logarithm. The formulas of non-financial variables can be followed in Table 3.

Table 3. Non-financial variables' abbreviations, formulas and explanations.

\begin{tabular}{|c|c|}
\hline Variable Abbreviation and Formula & Explanation \\
\hline$T M A X=\ln \left[\max \left(x_{1} \ldots x_{12}\right)\right]$ & $\begin{array}{c}\text { Natural logarithm of maximum tax arrears } \\
\text { over twelve month ends }\end{array}$ \\
\hline$T M E D=\ln \left[\right.$ median $\left.\left(x_{1} \ldots x_{12}\right)\right]$ & $\begin{array}{c}\text { Natural logarithm of median tax arrears over } \\
\text { twelve month ends }\end{array}$ \\
\hline $\begin{array}{c}\text { TCOUNT }=\sum_{k=1}^{12} T A_{k} \\
\text { where } T A_{k}=\{1 \text { if tax arrears } \geq 100 ; \text { else } 0\}\end{array}$ & $\begin{array}{l}\text { Number of months ending with tax arrears of } \\
100 \text { euros or more over twelve month ends }\end{array}$ \\
\hline$R D D=$ report submitted - report due & $\begin{array}{l}\text { Reporting delays of annual reports (calculated } \\
\text { in days) }\end{array}$ \\
\hline
\end{tabular}

Regarding annual reporting, in Estonia information about a non-submitted annual report is also publicly available via the Estonian Business Register. If a company in Estonia fails to submit an annual report in time, a warning of deletion from the register is issued and the company is obliged to submit the report within a specified extended term that is at least six months. In addition, the delaying firm can be fined. It has been found that delays over the legal deadline in submitting annual reports reflect a higher risk of a firm's bankruptcy (Lukason and Camacho-Miñano 2019). In case a company still fails to comply and presents no justified reason for non-compliance, the register may publish a public notice concerning the company's failure to submit the annual report within the prescribed term and invite creditors to notify their claims against the company and to request the conduct of a liquidation proceeding within six months after the date of public notice (State Gazette 2020, chp. 60). If no claims are presented, the company would be deleted from the register without a liquidation proceeding (State Gazette 2020, chp. 60). It has been found to be common for insolvent firms not to submit the annual report at all (Lukason 2013). Therefore, in case a firm is using debt, a delayed annual report can per se hold valuable information for failure prediction.

\subsection{Methods}

In a recent study about bankruptcy prediction in a 10-year horizon, five different commonly used methods were compared against each other, whereby logistic regression and neural networks proved to be superior over other approaches (Altman et al. 2020). The two methods would presumably perform well also for bank loan default prediction.

The first method applied in this paper is logistic regression (LR), which has been one of the most used methods in earlier relevant failure-prediction studies, as well as one of the most practiced methods by banks in their corporate default-prediction modelling (Altman and Sabato 2007; Ciampi 2015). Because this study aims to show if and how non-financial variables enhance bank loan default prediction accuracy, then the application of "classical" logistic regression is suitable for that purpose. In the context of an Estonian commercial bank, whole population of firms (defaulted and non-defaulted) is used, and thus the classes are very imbalanced. Namely, the share of defaulted observations is only $1.21 \%$. When 
using the LR method, this would usually cause misclassification errors for the minority group (defaulted firms), so in order to compensate for this, a weighting technique was used to equalize the two groups, as is the common practice in previous failure studies (see for example Altman et al. 2017; Calabrese and Osmetti 2013). Weighting enables obtaining a clear understanding, how well the two groups are distinguishable from each other, and also, a correct estimate for the Type I and Type II errors. The formulas to calculate weights for both groups are presented in Table 4.

Table 4. Formulas to calculate weights.

\begin{tabular}{cc}
\hline Weight for Defaulted Group & Weight for Non-Defaulted Group \\
\hline$W_{d}=\frac{0.5}{\text { share of defaulted firms }}$ & $W_{n d}=\frac{0.5}{\text { share of non-defaulted firms }}$ \\
\hline Source: own elaboration.
\end{tabular}

First, the univariate prediction abilities of all financial and non-financial variables were tested. Next, all the variables were categorized into three domains to perform a domainbased multivariate analysis: (a) financial ratios; (b) annual reporting delays; (c) tax arrears. It should be noted that because there is only one variable about the annual reporting delays, the univariate and domain-based accuracies equal for the specific circumstance. Finally, all variables from the three domains were combined to create the cross-domain model. Thus, three layers of analysis are applied. Correlation matrix of the applied independent variables has been provided in the Appendix A Table A3.

The second method used in this study is neural networks (in short, NN), which is a modern machine learning tool often applied in failure-prediction research, and thus, is hereby used to verify the initial results obtained with the classical LR method. For the NN, instead of weighting the two groups equal, a synthetic minority oversampling technique (SMOTE) was used to equalize the imbalances between the two groups of companies. That is achieved by multiplying defaulted observations to match the non-defaulted observations; therefore, the frequency totalling 12,745 observations in both groups. It must be noted that univariate prediction abilities of variables were calculated using only the logistic regression method, because neural networks require a multivariate setting to perform. NN was administered with one hidden layer, by applying sigmoid function throughout and using a 50/50 partition in between the training and test sets.

\section{Results and Discussion}

This section outlines the results by three layers of analysis and discusses the findings in respect to their importance to scientific literature and risk-management practice (in the banking sector). Descriptive statistics of the financial variables can be seen in Table 5 .

The $p$-values of Welch's robust ANOVA test being $\leq 0.05$ indicate that most of the ratios' means are significantly different through the two groups of firms, although $\leq 0.01$ differences become less frequent. The defaulted group indicates worse performance in all main domains analysed, i.e., liquidity, profitability, efficiency and solvency. Large differences of the minimum and maximum values combined with large standard deviations inside both groups' results indicate that there is no single cause or pathway to failure. The presence of different failure processes is reasoned with the use of a whole-population dataset from an Estonian commercial bank, which in essence makes the dataset quite heterogeneous. The result concerning the presence of different failure processes is also in line with previous failure research (e.g., Lukason and Laitinen 2016), and because of that, high prediction accuracies might not be achievable with financial ratios. The differences of means are statistically significant for all variables, except for ORA and FREOR (0.693 and 0.07, respectively). Therefore, the ORA variable reflects that in terms of a firm's efficiency, the means of the defaulted and non-defaulted groups are equal. In their defaultbased Italian study covering years 1999-2002, Bottazzi et al. (2011) found that productive efficiency reduced the risk of default; however, its importance decreased over time and was insignificant in the last year before the default, i.e., in principle providing the same result as 
the current finding, because this study uses data only one year prior to default. The track of significant variables matches well of what has been found in previous literature reviews about failure prediction (see e.g., Dimitras et al. 1996); thus, financial problems preceding default are generally similar to those occurring before bankruptcy, although there can be differences in their magnitude.

Table 5. Descriptive statistics of financial variables.

\begin{tabular}{|c|c|c|c|c|c|c|c|c|c|}
\hline Group & Statistic & CCLA & NWCA & NIA & NIOR & DA & ORA & FREOR & FREA \\
\hline \multirow{6}{*}{$\begin{array}{c}\text { Non- } \\
\text { defaulted }\end{array}$} & $\mathrm{N}$ & \multicolumn{8}{|c|}{12,745} \\
\hline & Mean & -0.13 & 0.24 & 0.12 & 0.12 & 0.44 & 1.92 & -0.017 & 0.002 \\
\hline & Median & -0.14 & 0.20 & 0.08 & 0.06 & 0.43 & 1.48 & 0.002 & 0.003 \\
\hline & Min. & -3.00 & -3.00 & -3.00 & -3.00 & 0.00 & 0.00 & -3.000 & -3.000 \\
\hline & Max. & 1.00 & 1.00 & 3.00 & 3.00 & 3.00 & 10.00 & 3.000 & 2.492 \\
\hline & Std. dev. & 0.34 & 0.34 & 0.23 & 0.40 & 0.27 & 1.75 & 0.302 & 0.068 \\
\hline \multirow{6}{*}{ Defaulted } & $\mathrm{N}$ & \multicolumn{8}{|c|}{156} \\
\hline & Mean & -0.26 & 0.17 & 0.02 & -0.01 & 0.61 & 1.86 & 0.003 & 0.009 \\
\hline & Median & -0.26 & 0.08 & 0.03 & 0.02 & 0.61 & 1.28 & 0.005 & 0.010 \\
\hline & Min. & -1.93 & -0.97 & -3.00 & -2.27 & 0.00 & 0.04 & -1.205 & -0.201 \\
\hline & Max. & 1.00 & 1.00 & 0.95 & 0.70 & 2.40 & 10.00 & 0.651 & 0.219 \\
\hline & Std. dev. & 0.38 & 0.38 & 0.40 & 0.36 & 0.35 & 1.85 & 0.130 & 0.037 \\
\hline \multicolumn{2}{|c|}{$\begin{array}{c}p \text {-value of ANOVA Welch } \\
\text { test }\end{array}$} & 0.000 & 0.019 & 0.002 & 0.000 & 0.000 & 0.693 & 0.070 & 0.025 \\
\hline
\end{tabular}

It is clearly visible that the defaulted companies have serious issues with tax arrears, while the non-defaulted have almost none (see Table 6). The mean value of TCOUNT for the defaulted firms is 5.6, which is well above the three times threshold, i.e., the point, when reached or exceeded, Back (2005) in his similar payment default setting discovered an important increase in the probability of permanent payment default. Back (2005) used a 2.5-year horizon; hence, the finding of TCOUNT mean value of 5.6 in current study with only one-year horizon is remarkable. In their bankruptcy-based Estonian study, the respective result by Lukason and Andresson (2019) for one-year horizon was 7.4. It can be assumed that defaulted firms either try to survive by aggressively evading tax obligations in favour of other creditors (for example, banks and key suppliers), or the firm has been left dormant because of not having perspective of continuing activities, and thus, the unpaid obligations accumulate further (until official insolvency proceedings).

Table 6. Descriptive statistics of non-financial variables.

\begin{tabular}{cccccc}
\hline Group & Statistic & TMAX & TCOUNT & TMED & RDD \\
\hline \multirow{4}{*}{ Non-defaulted } & $\mathrm{N}$ & \multicolumn{2}{c}{12,745} & & \\
& Mean & 1.20 & 0.57 & 0.33 & 12.87 \\
& Median & 0.00 & 0.00 & 0.00 & 0.00 \\
& Max. & 13.59 & 12.00 & 12.93 & 753.00 \\
& Std. dev. & 2.99 & 1.89 & 1.61 & 45.51 \\
\hline \multirow{5}{*}{ Defaulted } & $\mathrm{N}$ & & 156 & & \\
& Mean & 6.90 & 5.63 & 3.72 & 67.78 \\
& Median & 8.02 & 5.00 & 0.00 & 0.00 \\
& Max. & 12.03 & 12.00 & 12.03 & 548.00 \\
\hline \multirow{2}{*}{$p$-value of ANOVA Welch test } & 3.57 & 4.55 & 4.23 & 130.68 \\
\hline
\end{tabular}

Source: own elaboration. Minimum values zero for all tax variables and submission delays.

It was confirmed that the mean value of reporting delays was 55 days more for the defaulted firms compared to the non-defaulted, though median values for both groups were zero. It shows that a minority of firms with defaults had problems with timely 
reporting. Additionally, as the minimum and median values for the defaulted group are zero, it explains that, in general, delays in reporting would not directly indicate an increased risk of a payment default. Lukason (2013) found that the non-submission of reports in Estonia varies for different insolvency types and was more frequent in cases of a bankruptcy proceeding abatement, i.e., in a situation where the insolvent firm is assetless, and thus, managers have more incentives to hide financial information. The latter case is expectedly not very usual in cases of a commercial bank's corporate clients, as loans are guaranteed. Thus, in this context, the RDD variable could indicate that as explained in Section 2.1, a firm that has defaulted might not end up insolvent, so an incentive to hide financial information might also not be present.

Next, the univariate prediction abilities of the applied variables are presented in Table 7. In terms of financial variables, it can be followed that the best prediction capabilities come from solvency variables (DA and FREA), closely followed by liquidity (CCLA) and profitability (NIA and NIOR) variables. However, almost all non-financial variables outperform every financial variable, the latter of which have very weak prediction abilities, symbolizing more a "coin toss" situation. Reporting delays show slightly lower prediction accuracy than the best-performing financial variables, therefore being individually not useful for bank loan default prediction. Tax arrears have clearly the highest univariate prediction accuracies, specifically the maximum tax arrears variable (TMAX) with $84 \%$. Therefore, the companies that indicate large tax arrears are most likely to default. Lukason and Andresson (2019) arrived exactly at the same conclusion in their different bankruptcyoriented setting, where the maximum tax arrears variable had also the best univariate failure (bankruptcy) prediction accuracy $(85.9 \%)$.

Table 7. Univariate prediction accuracies of variables (\%).

\begin{tabular}{clcccc}
\hline & \multicolumn{2}{l}{ Financial Variables } & \multicolumn{2}{c}{ Non-Financial Variables } \\
\hline CCLA & 58.6 & DA & 61.2 & RDD & 59.6 \\
NWCA & 53.6 & ORA & 51.3 & TMAX & 84.0 \\
NIA & 57.9 & FREOR & 50.8 & TMED & 71.3 \\
NIOR & 57.8 & FREA & 60.0 & TCOUNT & 78.4 \\
\hline \multicolumn{2}{l}{ Source: own elaboration. }
\end{tabular}

This study focuses on and describes only the highest prediction accuracies achieved by using either of the two methods. Financial ratios show modest prediction capabilities because only a $65.9 \%$ accuracy was reached. In a comparable setting, Back (2005) achieved $72 \%$. It also confirms an important finding in prior failure literature, because several previous studies (e.g., Altman and Sabato 2007; Ciampi 2015) have shown that failure prediction models that are based on financial variables and perform well on large public firms tend to show poor prediction accuracies for SMEs. Additionally, financial reports often fail to indicate problems in the SMEs' financial health even one year before bankruptcy (Lukason and Laitinen 2019), while the moment of default occurs much earlier. Thus, the first main finding of the paper is that at least in cases of quality loan portfolios, financial ratios are not useful to predict loan defaults.

The reporting delay variable shows almost no prediction capability for the defaulted group with only $29.5 \%$. Thus, this variable is not suitable for payment default prediction either. Although, for example, in their study Lukason and Camacho-Miñano (2019) showed that delays in reporting indeed do show increased risk of failure, the differences in the risk for (non-)delayers are not substantial enough to enable high-precision prediction. Probably the usage of this variable (i.e., RDD) would make more sense in cases of applying a more severe failure definition, e.g., start of insolvency proceedings or declaration of bankruptcy, or when focusing on firms that do not use bank loans, as banks might monitor the fulfillment of annual report submission obligations.

The tax arrears domain combining TMAX, TMEDIAN and TCOUNT variables strongly outperforms all other domains (see Table 8). Prediction accuracy for the defaulted group is $80.9 \%$ and $83.5 \%$ overall. The result confirms initial findings of univariate prediction 
accuracies and is comparable with the Back (2005) study using a similar dependent variable, where $86.3 \%$ default prediction accuracy was achieved by using only non-financial variables. Lukason and Andresson (2019) reached an even higher accuracy (89.5\%) by using bankruptcy as the dependent variable and the same independent variables as in the current study (tax arrears for 12 months prior to event date). Still, the latter accuracy is not surprising because the declaration of insolvency at court can only occur in the circumstances of unpaid claims and the only pending questions would be: (a) how many firms go bankrupt because of unpaid tax claims, (b) what is the proportion of healthy firms with (episodic) tax arrears.

Table 8. Domain-based and across-domain multivariate prediction accuracies (\%).

\begin{tabular}{ccccccc}
\hline \multirow{2}{*}{ Domain } & \multicolumn{2}{c}{ Logistic Regression (LR) } & \multicolumn{3}{c}{ Neural Networks (NN) } \\
\cline { 2 - 6 } & D & ND & All & D & ND & All \\
\hline Financial ratios & 59 & 64.8 & 61.9 & 71.7 & 60.2 & 65.9 \\
Reporting delays & 29.5 & 89.7 & 59.6 & 28.9 & 90.2 & 59.4 \\
Tax arrears & 80.1 & 85.9 & 83 & 80.9 & 86.2 & 83.5 \\
All combined & 80.8 & 86.7 & 83.7 & 88.6 & 89.7 & 89.1 \\
\hline
\end{tabular}

Source: own elaboration. D—defaulted, ND—non-defaulted.

Finally, a multivariate model was constructed that included all the aforementioned three domains. Prediction accuracy was $88.6 \%$ for the defaulted group and $89.1 \%$ overall. As can be seen from Table 8, in terms of methods used in the study, the modern machine learning method (NN) outperformed the classical statistical method (LR). For NN, the most important predictors of default were TCOUNT (100\% normalized importance rate), FREA (98.2\%) and TMED (75.6\%) (see Appendix A Table A2). Due to high multicollinearity between the variables (see the correlation table in Appendix A Table A3), logistic regression models are not presented, because the variables' estimations would be biased.

The main theoretical implication of the paper is that tax arrears offer high predictive performance when forecasting bank loan payment defaults. Such implication is important because there is no prior literature where tax arrears would be used to predict loan defaults. Tax arrears outperform the most common financial ratios previously used in the failure prediction literature. It is important to note that one year prior to bankruptcy, as shown by Lukason and Andresson (2019), financial ratios had a 79.5\% prediction accuracy; while in the context of defaults in this paper, the accuracy was only $65.9 \%$. This indicates that companies default rather unexpectedly, i.e., it will not be seen coming from the companies' financial reports. A potential explanation for this finding was given by Laitinen and Lukason (2014, p. 827), who found that Estonian firms generally lacked financial flexibility to withstand external shocks and other specific external events. The present study's conclusion in general confirms previous research, as the inclusion of non-financial information does greatly enhance failure-prediction accuracy. In addition, the paper clearly shows that debtors first leave unpaid the obligations that are less vital for them, i.e., a clear pecking-order behaviour is present concerning satisfying different types of claims in the failure process.

The results also indicate the prevalence of a quick failure process among firms qualified to obtain a bank loan. Such a failure process has been proposed in earlier studies ( $\mathrm{D}^{\prime}$ Aveni 1989; Laitinen 1991) and found to be especially frequent in the SME segment (Lukason et al. 2016; Lukason and Laitinen 2019). The main characteristic of a given failure process is that even the last annual report, which is submitted in a timely manner, does not indicate financial problems. A possible solution for the latter problem would be quarterly (or even more frequent) reports, although even these might not capture some of the root causes of liquidity problems (e.g., uncollectable receivables) quickly enough. Therefore, the presence of tax arrears serves as a valuable real-time proxy of poor liquidity (management).

The main practical implication of this study is that from a creditor's point of view, earlier payment disturbances, namely tax arrears, are a clear sign of increased default 
risk. This information should be considered by banks when granting credit to borrowers and also in the context of an existing loan portfolio, i.e., to take necessary measures in a timely manner in order to minimize potential losses. Evidently, the larger the tax arrears and the more frequent they are, the higher the risk of a loan payment default. Because tax arrears' information is publicly available on a daily or monthly basis in many countries, it offers high practical value for creditors. It should help in decision-making when financial reporting is delayed or opaque, both of which are especially inherent to companies with increased failure risk (especially in the SME segment). The results of the models in this study indicate that even the sole usage of tax arrears variables without other types of predictors provides a sufficiently high accuracy for practical use. As of today, established financial institutions have already implemented a previous-payment behaviour component in their credit-scoring models, albeit mostly in the form of data about disturbances originating from their own organization. The present study confirms why it is essential to include tax arrears information into credit-scoring models as well. Concerning the latter, the practical application could be much more enhanced than the academic approach presented in this paper, for example, accounting for real-time information and big data about tax payment behaviour and tax arrears combined with other information sources (see e.g., Chang and Ramachandran 2017; Chang et al. 2020).

\section{Conclusions}

The study aimed to compare the accuracy of financial ratios, tax arrears and annual report submission delays for predicting bank-loan defaults. For the analysis, logistic regression and neural networks methods were applied on the whole-population dataset consisting of defaulted and non-defaulted companies originating from an Estonian commercial bank.

The results showed that by including non-financial variables, the accuracy of loandefault prediction increases remarkably. The study provided several implications. As for the theoretical implication, it was discovered that tax arrears provide high prediction accuracy to foresee bank-loan defaults. At the same time, even though prior research has found that occurrences of reporting delays can effectively indicate an increased failure risk, the phenomenon does not suit to predict loan defaults. The latter problem is also inherent to financial ratios, which otherwise have been applied with high accuracy in bankruptcy prediction settings. As for the practical implication, the findings should help lenders to consider the role of previous payment history, in the form of tax arrears, in loan defaults prediction. Incorporating tax arrears' information to forecasts would enable the lender to take timely actions to minimize potential financial losses.

As with each study, this paper is not free from limitations. The results of the study are mainly transferrable to commercial banks, which have high-quality portfolios, because the defaults accounted for only $1.2 \%$ of the population analysed. The latter was an aggregate figure summarized over a six-year period, leading to an average annual rate of $0.2 \%$. In the case of creditors lending more liberally and having worse portfolio qualities, financial ratios as predictors might play a more important role as in this study. In addition, tax regulations and their enforcement, but also insolvency legislation, can largely vary through different jurisdictions, which should be accounted when applying tax arrears variables. For instance, in some environments the regulations might hinder the emergence of tax arrears before defaulting on debt from the private sector, one example of which is the bank-loan default. Lastly, this study applied financial information from the annual reports, which are officially published with a one-year step. Probably the availability of up-to-date financial reports, for instance with quarterly or even monthly frequency, would to some extent enhance the predictive power of financial ratios. Although in the SME segment such reports are missing, they can be demanded by setting relevant terms in the loan contracts, but their reliability as being non-audited always remains questionable.

This study has filled a gap in modern firm-failure research by analysing tax arrears in the context of loan-payment defaults. Future research could elaborate on the prior-payment 
concept to test how payment history inside the credit institution itself would compare with or accompany tax arrears to predict failure. In addition, information about other types of defaults could enhance the prediction accuracies even further. Lastly, managerial background could be a crucial predictor in the SME segment (e.g., Back 2005; Liang et al. 2016; Süsi and Lukason 2019).

Author Contributions: Both authors contributed to all parts. Both authors have read and agreed to the published version of the manuscript.

Funding: Authors acknowledge financial support from the Estonian Research Council's grant PRG791 "Innovation Complementarities and Productivity Growth".

Institutional Review Board Statement: Not applicable.

Informed Consent Statement: Not applicable.

Data Availability Statement: Data sharing restricted by a third party.

Acknowledgments: We acknowledge that access to some data was financed by Estonian Research Infrastructures Roadmap project "Infotechnological Mobility Observatory (IMO)". This study is an extended version of an earlier unpublished paper by the first author.

Conflicts of Interest: The authors declare no conflict of interest. 


\section{Appendix A}

Table A1. Failure prediction articles using non-financial variables and/or using loan default as a dependent variable.

\begin{tabular}{|c|c|c|c|c|c|}
\hline Author & Country & Sample Size & Non-Financial Variables in Prediction Models & Dependent Variable & Accuracy \\
\hline Zizi et al. (2020) & Morocco & 90 & None (i.e., only financial ratios) & defaulted/non-defaulted & $84.4 \%$ (TS) \\
\hline Altman et al. (2020) & Finland & 51,099 & $\begin{array}{c}\text { firm type; age; industry bankruptcy risk; prior defaults; } \\
\text { industry payment default risk; delayed reporting; } \\
\text { auditor's report; payment delays }>60 \text { days; number of } \\
\text { payment delays }>60 \text { days; delays / total assets; board } \\
\text { characteristics }\end{array}$ & bankrupt /non-bankrupt & $\begin{array}{c}>93 \% \text { (test sample, in short } \\
\text { TS) }\end{array}$ \\
\hline Ciampi et al. (2020) & Italy & 1200 & $\begin{array}{c}\text { past due exposures }>60 \text { days (E60D); (E60D)/turnover; } \\
\text { (E60D)/EBITDA; (E60D)/cash flow; (E60D)/bank } \\
\text { loans; (E60D)/financial debt; number of payment } \\
\text { delays }>60 \text { days; number non-remedied payment } \\
\text { delays }>60 \text { days; number of cumulative payment } \\
\text { delays }>60 \text { days; number of cumulative non-remedied } \\
\text { payment delays }>60 \text { days }\end{array}$ & defaulted/non-defaulted & $85.3 \%$ (TS) \\
\hline $\begin{array}{l}\text { Lukason and Andresson } \\
\text { (2019) }\end{array}$ & Estonia & 4515 & tax arrears & bankrupt /non-bankrupt & $\begin{array}{l}91.3 \% \text { (holdout sample, in } \\
\text { short HOS) }\end{array}$ \\
\hline Ciampi (2018) & Italy & 382 & $\begin{array}{c}\text { corporate social responsibility (CSR) towards } \\
\text { employees; CSR towards customers; CSR towards } \\
\text { suppliers; CSR towards the local community; CSR } \\
\text { environmental aspects }\end{array}$ & defaulted/non- defaulted & $82.8 \%$ (HOS) \\
\hline Altman et al. (2017) & International & $2,640,000$ & $\begin{array}{c}\text { year of bankruptcy; size; age; industry; country of } \\
\text { origin }\end{array}$ & failed/non-failed & $82.3 \%$ (TS) \\
\hline Höglund (2017) & Finland & 768 & $\begin{array}{l}\text { industry risk of payment defaults; industry risk of } \\
\text { bankruptcy }\end{array}$ & tax default & $73.8 \%$ (TS) \\
\hline Ciampi (2015) & Italy & 934 & $\begin{array}{l}\text { audit committee; board size; CEO turnover; } \\
\text { CEO-duality; creditor ownership; director turnover; } \\
\text { board member education; number of CEOs and } \\
\text { chairpersons; outside directors present but in a } \\
\text { proportion lower than } 50 \% \text {; outside directors present } \\
\text { but in a proportion equal or higher than } 50 \% \text {; } \\
\text { ownership concentration; } \% \text { held by institutions; } \% \\
\text { held by managers and directors }\end{array}$ & defaulted/non-defaulted & 87\% (HOS) \\
\hline
\end{tabular}


Table A1. Cont.

\begin{tabular}{|c|c|c|c|c|c|}
\hline Author & Country & Sample Size & Non-Financial Variables in Prediction Models & Dependent Variable & Accuracy \\
\hline $\begin{array}{c}\text { McCann and } \\
\text { McIndoe-Calder (2015) }\end{array}$ & Ireland & 6745 & $\begin{array}{c}\text { manager or owner has been with the firm } 10 \text { years or } \\
\text { more; industry sector }\end{array}$ & defaulted/non-defaulted & $80.6 \%$ (TS) \\
\hline Bhimani et al. (2013) & Portugal & 17,000 & $\begin{array}{l}\text { financial support from partners; type of management; } \\
\text { ownership of assets; management skill }\end{array}$ & time to loan default & $90.1 \%(\mathrm{HOS})$ \\
\hline Laitinen (2011) & Finland & 65,164 & $\begin{array}{l}\text { industry; age; board characteristics; audit report; } \\
\text { number of payment defaults; number of payment } \\
\text { delays; number of positive payment signals; firm type; } \\
\text { months to the date of last financial reports; length of } \\
\text { last accounting period; }\end{array}$ & viable/non-viable & $89.2 \%$ (TS) \\
\hline Bhimani et al. (2010) & Portugal & 31,025 & size; age; industry; geographic regions & defaulted/non-defaulted & $77.9 \%$ (HOS) \\
\hline Altman et al. (2010) & UK & $5,800,000$ & $\begin{array}{c}\text { audit information; late filing; age; subsidiary; size; } \\
\text { industry; no cashflow statement; country court } \\
\text { judgement }\end{array}$ & failed/non-failed & $78 \%$ (HOS) \\
\hline Back (2005) & Finland & 3199 & $\begin{array}{l}\text { management relation disturbance; management own } \\
\text { payment disturbance; payment disturbances; payment } \\
\text { delays; age; group membership; size }\end{array}$ & defaulted/non-defaulted & $81.2 \%$ (HOS) \\
\hline
\end{tabular}

Source: own elaboration. Note: in case a paper found several prediction accuracies, for example for different methods, the table reflects only the highest accuracy. 
Table A2. Overview of independent variable importance in the neural networks.

\begin{tabular}{ccc}
\hline Variable & Importance & Normalized Importance \\
\hline TMAX & 0.070 & $51.8 \%$ \\
TCOUNT & 0.136 & $100.0 \%$ \\
TMEDIAN & 0.103 & $75.6 \%$ \\
CCLA & 0.078 & $57.1 \%$ \\
NWCA & 0.065 & $47.6 \%$ \\
NIA & 0.081 & $59.8 \%$ \\
NIOR & 0.077 & $56.7 \%$ \\
DA & 0.070 & $51.7 \%$ \\
ORA & 0.062 & $46.0 \%$ \\
FREOR & 0.073 & $53.7 \%$ \\
FREA & 0.133 & $98.2 \%$ \\
RDD & 0.051 & $37.8 \%$ \\
\hline
\end{tabular}

Source: own elaboration.

Table A3. Correlation table.

\begin{tabular}{|c|c|c|c|c|c|c|c|c|c|c|c|c|}
\hline Variable & TMAX & TCOUNT & TMEDIAN & CCLA & NWCA & NIA & NIOR & DA & ORA & FREOR & FREA & RDD \\
\hline TMAX & 1 & $0.774 * *$ & $0.572 * *$ & $-0.143 * *$ & -0.115 ** & $-0.061 * *$ & $-0.048 * *$ & $0.125 * *$ & 0.003 & $0.024 * *$ & 0.021 * & 0.147 ** \\
\hline TCOUNT & $0.774 * *$ & 1 & 0.903 ** & -0.130 ** & -0.095 ** & $-0.059 * *$ & $-0.048 * *$ & 0.117 ** & 0.006 & 0.023 ** & 0.030 ** & 0.152 ** \\
\hline TMEDIAN & $0.572 * *$ & 0.903 ** & 1 & -0.112 ** & $-0.079 * *$ & -0.050 ** & $-0.037 * *$ & 0.102 ** & 0.005 & 0.017 & 0.027 *** & 0.136 ** \\
\hline CCLA & $\begin{array}{l}0.5 / 2 \\
-0.143 * *\end{array}$ & $\begin{array}{l}0.130 \text { ** } \\
-0.903\end{array}$ & -0.112 ** & $\begin{array}{c}-0.112 \\
1\end{array}$ & $0.660 * *$ & $0.345 * *$ & $0.168 * *$ & $-0.701 * *$ & $-0.156^{* *}$ & -0.045 ** & $-0.049 * *$ & -0.024 ** \\
\hline NWCA & -0.115 ** & -0.095 ** & -0.079 ** & $0.660 * *$ & 1 & 0.347 ** & 0.103 ** & -0.622 ** & $0.109 * *$ & $-0.039 * *$ & $-0.038 * *$ & -0.016 \\
\hline NIA & -0.061 ** & $-0.059 * *$ & -0.050 ** & 0.345 ** & $0.347^{* *}$ & 1 & $0.422 * *$ & $-0.354 * *$ & 0.059 ** & $-0.110 * *$ & -0.200 ** & 0.011 \\
\hline NIOR & -0.048 ** & -0.048 ** & $-0.037 * *$ & 0.168 ** & 0.103 ** & $0.422 * *$ & 1 & $-0.205 * *$ & $-0.151^{* *}$ & $-0.677 * *$ & $-0.354^{* *}$ & 0.012 \\
\hline DA & $0.125 * *$ & 0.117 ** & 0.102 ** & $-0.701 * *$ & -0.622 ** & -0.354 ** & -0.205 ** & 1 & 0.158 ** & $0.109 * *$ & $0.093 * *$ & $0.021^{*}$ \\
\hline ORA & 0.003 & 0.006 & 0.005 & -0.156 *** & $0.109 * *$ & $0.059 * *$ & -0.151 ** & $0.158 * *$ & $\begin{array}{c}0.100 \\
1\end{array}$ & 0.066 ** & 0.045 ** & -0.036 ** \\
\hline FREOR & $0.024 * *$ & $0.023 * *$ & 0.017 & $-0.045 * *$ & $-0.039 * *$ & -0.110 ** & $-0.677 * *$ & 0.109 ** & $0.066 * *$ & 1 & $0.504 * *$ & -0.004 \\
\hline FREA & 0.021 * & 0.030 ** & $0.027^{* * *}$ & $-0.049 * *$ & $-0.038^{* *}$ & -0.200 ** & $-0.354 * *$ & 0.093 ** & 0.045 ** & $0.504 * *$ & 1 & 0.014 \\
\hline RDD & $0.147 * *$ & $0.152 * *$ & $0.136^{* *}$ & $-0.024 * *$ & -0.016 & 0.011 & 0.012 & 0.021 * & -0.036 * & -0.004 & 0.014 & 1 \\
\hline
\end{tabular}

Source: own elaboration. Note: * Correlation is significant at the 0.05 level (2-tailed). ${ }^{* *}$. Correlation is significant at the 0.01 level (2-tailed).

\section{References}

Alaka, Hafiz A., Lukumon O. Oyedele, Hakeem A. Owolabi, Vikas Kumar, Saheed O. Ajayi, Olugbenga O. Akinade, and Muhammad Bilal. 2018. Systematic review of bankruptcy prediction models: Towards a framework for tool selection. Expert Systems with Applications 94: 164-84. [CrossRef]

Altman, Edward I. 1968. Financial Ratios, Discriminant Analysis and the Prediction of Corporate Bankruptcy. The Journal of Finance 23: 589-609. [CrossRef]

Altman, Edward I., and Paul Narayanan. 1997. An International Survey of Business Failure Classification Models. Financial Markets, Institutions and Instruments 6: 1-57. [CrossRef]

Altman, Edward I., and Gabriele Sabato. 2007. Modelling credit risk for SMEs: Evidence from the U.S. market. Abacus 43: 332-57. [CrossRef]

Altman, Edward I., Gabriele Sabato, and Nick Wilson. 2010. The value of non-financial information in small and medium-sized enterprise risk management. The Journal of Credit Risk 6: 1-33. [CrossRef]

Altman, Edward I., Małgorzata Iwanicz-Drozdowska, Erkki K. Laitinen, and Arto Suvas. 2017. Financial Distress Prediction in an International Context: A Review and Empirical Analysis of Altman's Z-Score Model. Journal of International Financial Management and Accounting 28: 131-71. [CrossRef]

Altman, Edward I., Małgorzata Iwanicz-drozdowska, Erkki K. Laitinen, and Arto Suvas. 2020. A Race for Long Horizon Bankruptcy Prediction. Applied Economics 52: 4092-111. [CrossRef]

Atiya, Amir F. 2001. Bankruptcy prediction for credit risk using neural networks: A survey and new results. IEEE Transactions on Neural Networks 12: 929-35. [CrossRef]

Back, Peter. 2005. Explaining financial difficulties based on previous payment behavior, management background variables and financial ratios. European Accounting Review 14: 839-68. [CrossRef]

Balcaen, Sofie, and Hubert Ooghe. 2006. 35 years of studies on business failure: An overview of the classic statistical methodologies and their related problems. British Accounting Review 38: 63-93. [CrossRef]

Basel Committee on Banking Supervision. 2016. Prudential Treatment of Problem Assets-Definitions of Non-Performing Exposures and Forbearance. Basel: Basel Committee on Banking Supervision, pp. 1-45. Available online: https://www.bis.org/bcbs/publ/d403 .htm (accessed on 20 November 2020).

Beaver, William H. 1966. Financial Ratios as Predictors of Failure. Journal of Accounting Research 4: 71-111. [CrossRef] 
Bellovary, Jodi L., Don E. Giacomino, and Michael D. Akers. 2007. A Review of Bankruptcy Prediction Studies: 1930-Present. Journal of Financial Education 33: 1-42. Available online: https:/ / www.jstor.org/stable/41948574 (accessed on 20 November 2020).

Bhimani, Alnoor, Mohammed Azzim Gulamhussen, and Samuel Da-Rocha Lopes. 2010. Accounting and non-accounting determinants of default: An analysis of privately-held firms. Journal of Accounting and Public Policy 29: 517-32. [CrossRef]

Bhimani, Alnoor, Mohammed Azzim Gulamhussen, and Samuel Da-Rocha Lopes. 2013. The Role of Financial, Macroeconomic, and Non-financial Information in Bank Loan Default Timing Prediction. European Accounting Review 22: 739-63. [CrossRef]

Bottazzi, Giulio, Marco Grazzi, Angelo Secchi, and Federico Tamagni. 2011. Financial and economic determinants of firm default. Journal of Evolutionary Economics 21: 373-406. [CrossRef]

Calabrese, Raffaella, and Silvia Angela Osmetti. 2013. Modelling small and medium enterprise loan defaults as rare events: The generalized extreme value regression model. Journal of Applied Statistics 40: 1172-88. [CrossRef]

Camacho-Miñano, Maria-del-Mar, Maria-Jesus Segovia-Vargas, and David Pascual-Ezama. 2015. Which Characteristics Predict the Survival of Insolvent Firms? An SME Reorganization Prediction Model. Journal of Small Business Management 53: 340-54. [CrossRef]

Chang, Victor, and Muthu Ramachandran. 2017. Financial modeling and prediction as a service. Journal of Grid Computing 15: 177-95. [CrossRef]

Chang, Victor, Raul Valverde, Muthu Ramachandran, and Chung-Sheng Li. 2020. Toward business integrity modeling and analysis framework for risk measurement and analysis. Applied Sciences 10: 3145. [CrossRef]

Ciampi, Francesco. 2015. Corporate governance characteristics and default prediction modeling for small enterprises. An empirical analysis of Italian firms. Journal of Business Research 68: 1012-25. [CrossRef]

Ciampi, Francesco. 2018. Using Corporate Social Responsibility Orientation Characteristics for Small Enterprise Default Prediction. WSEAS Transactions on Business and Economics 15: 113-27. Available online: https://www.wseas.org/multimedia/journals/ economics/2018/a265907-592.php (accessed on 20 November 2020).

Ciampi, Francesco, Valentina Cillo, and Fabio Fiano. 2020. Combining Kohonen maps and prior payment behavior for small enterprise default prediction. Small Business Economics 54: 1007-39. [CrossRef]

D'Aveni, Richard A. 1989. The aftermath of organizational decline: A longitudinal analysis study of the strategic and managerial characteristics of declining firms. Academy of Management Journal 32: 577-605. [CrossRef]

Dias, Artur, and Aurora A.C. Teixeira. 2017. The anatomy of business failure: A qualitative account of its implications for future business success. European Journal of Management and Business Economics 26: 2-20. [CrossRef]

Dimitras, Augustinos I., Stelios H. Zanakis, and Constantin Zopounidis. 1996. A survey of business failures with an emphasis on prediction methods and industrial applications. European Journal of Operational Research 90: 487-513. [CrossRef]

European Commission. 2020. SME Definition. Brussels: European Commission. Available online: https://ec.europa.eu/growth/smes/ sme-definition_en (accessed on 20 November 2020).

Gabbi, Giampaolo, Michele Giammarino, and Massimo Matthias. 2020. Die hard: Probability of default and soft information. Risks 8: 46. [CrossRef]

Headd, Brian. 2003. Redefining Business Success: Distinguishing between Closure and Failure. Small Business Economics 21: 51-61. [CrossRef]

Höglund, Henrik. 2017. Tax payment default prediction using genetic algorithm-based variable selection. Expert Systems with Applications 88: 368-75. [CrossRef]

Iwanicz-Drozdowska, Małgorzata, Erkki K. Laitinen, Arto Suvas, and Edward I. Altman. 2016. Financial and nonfinancial variables as long-horizon predictors of bankruptcy. The Journal of Credit Risk 12: 49-78. [CrossRef]

Laitinen, Erkki K. 1991. Financial ratios and different failure processes. Journal of Business Finance E Accounting 18: 649-73. [CrossRef]

Laitinen, Erkki K. 1999. Predicting a corporate credit analyst's risk estimate by logistic and linear models. International Review of Financial Analysis 8: 97-121. [CrossRef]

Laitinen, Erkki K. 2008. Data system for assessing probability of failure in SME reorganization. Industrial Management E Data Systems 108: 849-66. [CrossRef]

Laitinen, Erkki K. 2011. Assessing viability of Finnish reorganization and bankruptcy firms. European Journal of Law and Economics 31: 167-98. [CrossRef]

Laitinen, Erkki K., and Teija Laitinen. 2009. Audit Report in Payment Default Prediction: A Contingency Approach. International Journal of Auditing 13: 259-80. [CrossRef]

Laitinen, Erkki K., and Oliver Lukason. 2014. Do firm failure processes differ across countries: Evidence from Finland and Estonia. Journal of Business Economics and Management 15: 810-32. [CrossRef]

Liang, Deron, Chia-Chi Lu, Chih-Fong Tsai, and Guan-An Shih. 2016. Financial ratios and corporate governance indicators in bankruptcy prediction: A comprehensive study. European Journal of Operational Research 252: 561-72. [CrossRef]

Lukason, Oliver. 2013. Firm bankruptcies and violations of law: An analysis of different offences. (Dis)Honesty in Management 10: 127-46. [CrossRef]

Lukason, Oliver, and Art Andresson. 2019. Tax Arrears versus Financial Ratios in Bankruptcy Prediction. Journal of Risk and Financial Management 12: 187. [CrossRef]

Lukason, Oliver, and Maria-del-Mar Camacho-Miñano. 2019. Bankruptcy Risk, Its Financial Determinants and Reporting Delays: Do Managers Have Anything to Hide? Risks 7: 77. [CrossRef] 
Lukason, Oliver, and Erkki K. Laitinen. 2016. Failure processes of old manufacturing firms in different European countries. Investment Management and Financial Innovations 13: 310-21. [CrossRef]

Lukason, Oliver, and Erkki K. Laitinen. 2019. Firm failure processes and components of failure risk: An analysis of European bankrupt firms. Journal of Business Research 98: 380-90. [CrossRef]

Lukason, Oliver, and Artjom Urbanik. 2013. Why Reorganization of Firms Fails: Evidence from Estonia. Estonian Discussions on Economic Policy 21: 73-84. [CrossRef]

Lukason, Oliver, Erkki K. Laitinen, and Arto Suvas. 2016. Failure processes of young manufacturing micro firms in Europe. Management Decision 54: 1966-85. [CrossRef]

McCann, Fergal, and Tara McIndoe-Calder. 2015. Firm size, credit scoring accuracy and banks' production of soft information. Applied Economics 47: 3594-611. [CrossRef]

State Gazette. 2020. Commercial Code. Available online: https:/ / www.riigiteataja.ee/en/eli/522062017003/consolide (accessed on 20 November 2020).

Statistics Estonia. 2020. GDP Chain-Linked Volume Change (Seasonally and Working Day Adjusted). Available online: https: / / www.stat.ee/ 68589 (accessed on 20 November 2020).

Sun, Jie, Hui Li, Qing-Hua Huang, and Kai-Yu He. 2014. Predicting financial distress and corporate failure: A review from the state-of-the-art definitions, modeling, sampling, and featuring approaches. Knowledge-Based Systems 57: 41-56. [CrossRef]

Süsi, Virgo, and Oliver Lukason. 2019. Corporate governance and failure risk: Evidence from Estonian SME population. Management Research Review 42: 703-20. [CrossRef]

Weitzel, William, and Ellen Jonsson. 1989. Decline in Organizations: A Literature Integration and Extension. Administrative Science Quarterly 34: 91-109. [CrossRef]

Wu, Wei-Wen. 2010. Beyond business failure prediction. Expert Systems with Applications 37: 2371-76. [CrossRef]

Xu, Ming, and Chu Zhang. 2009. Bankruptcy prediction: The case of Japanese listed companies. Review of Accounting Studies 14: 534-58. [CrossRef]

Zizi, Youssef, Mohamed Oudgou, and Abdeslam El Moudden. 2020. Determinants and predictors of SMEs' financial failure: A Logistic regression approach. Risks 8: 107. [CrossRef] 